\title{
Redactioneel
}

\section{De Dienstenrichtlijn: zoeken naar de balans tussen de markt en ruimtelijke ordening}

\author{
Prof. mr. dr. J. (Jurian) Langer*
}

Op 30 januari 2018 heeft het Hof van Justitie van de Europese Unie (hierna: het Hof) arrest gewezen in de gevoegde zaken College van Burgemeester en Wethouders van de gemeente Amersfoort/X (C-360/15) en Visser Vastgoed Beleggingen BV/Raad van de gemeente Appingedam (C-31/16). Gelet op de hete hangijzers in deze zaken is door velen reikhalzend naar dit arrest uitgekeken. Het is het wachten waard geweest. Het arrest is zonder twijfel baanbrekend en verschaft op cruciale punten duidelijkheid. Het Hof bepaalt dat detailhandel in goederen is aan te merken als een dienst in de zin van de Dienstenrichtlijn en dat de richtlijn van toepassing is in situaties zonder grensoverschrijdend element. Ook maakt het Hof duidelijk dat bepaalde voorschriften inzake ruimtelijke ordening getoetst moeten worden aan de richtlijn.

Anticiperend op de brede implicaties van het oordeel van het Hof heeft het Utrecht Centre for Water, Oceans and Sustainability Law snel na het verschijnen van het arrest een symposium georganiseerd. Dit symposium, onder het dagvoorzitterschap van Chris Backes, vond plaats op vrijdag 16 februari 2018. Tijdens het symposium hebben verschillende sprekers vanuit hun eigen visie en achtergrond het arrest en de gevolgen ervan geduid. Het symposium bestond uit twee delen. In het eerste deel lag de focus op het duiden van het arrest met een horizontale Europeesrechtelijke blik. De bijdragen zijn

\footnotetext{
Prof. mr. dr. J. Langer is 'agent' (procesgemachtigde) voor de Nederlandse regering in procedures bij het Hof van Justitie van de EU en hoofd van het Hofcluster bij het ministerie van Buitenlandse Zaken. In zijn hoedanigheid als agent is hij betrokken geweest bij het in dit themanummer besproken arrest. Hij is ook als bijzonder hoogleraar Europees recht en de nationale rechtsorde verbonden aan de Rijksuniversiteit Groningen. Dit gastredactioneel is geschreven op persoonlijke titel.
}

in dit deel verzorgd door Marianne Gijzen (ministerie van Buitenlandse Zaken), Marleen Botman (Pels Rijcken/VU Amsterdam) en Patrick van den Berghe (ministerie van Economische Zaken en Klimaat), waarin zij het arrest bespraken in het licht van onder meer de vaste rechtspraak van het Hof inzake de verhouding tussen het vrij verkeer van goederen en diensten en de totstandkomingsgeschiedenis van de richtlijn. In het tweede deel van het symposium is het arrest bekeken met een (meer) nationaalrechtelijke blik. Henk Gierveld (Universiteit Utrecht) ging in op de betekenis van het arrest voor de rechtspraak van de Afdeling, terwijl Tonny Nijmeijer (Radboud Universiteit Nijmegen) alsmede Koos Seerden/Ruud Louwes (Rho adviseurs) in hun bijdragen hun visie gaven op de praktische uitwerking van het arrest in de context van het ruimtelijke ordeningsrecht. Deze bijdragen werden rechtsvergelijkend gecomplementeerd met een Duitse respectievelijk Belgische invalshoek door de bijdragen van Jens Wahlhäuser (Bundesministerium für Umwelt, Naturschutz, Bau und Reaktorsicherheit) alsmede van Isabelle Larmuseau en Matthias Strubbe (LDR Advocaten). In dit themanummer van TO zijn de verschillende bijdragen van de sprekers uitgewerkt tot artikelen.

Zoals gehoopt was het een inspirerend symposium met levendige discussies. Prachtig vond ik de interactie tussen de Europarechtlern (waartoe ikzelf hoor) en de verschillende nationale experts op het gebied van het ruimtelijke ordeningsrecht (met ook een gedegen kennis van het Europees recht). Vaak worden het Europees recht en het nationale recht gezien als twee verschillende werelden. Dit terwijl zij in hoge mate met elkaar verweven zijn en niet zonder elkaar kunnen. De prejudiciële procedure van art. 267 van het Verdrag betreffende de werking van de Europese Unie (VWEU) is daarbij de cru- 
ciale schakel tussen deze twee werelden. In de woorden van het Hof: het is de dialoog tussen de nationale rechter en het Hof. ${ }^{1}$ Zo ook in dit arrest van 30 januari 2018, dat voortvloeit uit prejudiciële vragen van de Hoge Raad en de Afdeling bestuursrechtspraak van de Raad van State (hierna: de Afdeling). Deze dialoog tussen beide rechtsgebieden is tijdens het symposium in wezen doorgezet. Verschillende experts hebben elk vanuit hun eigen achtergrond het arrest geduid. Hoewel wij allemaal met het Europees recht bezig zijn, verschilt het perspectief waarmee naar het arrest van het Hof wordt gekeken. De Europarechtlern nemen het Europees recht en de eigen systematiek ervan als vertrekpunt, terwijl andere experts het Europees recht vaak aanvliegen vanuit het perspectief van het nationale recht. Wij spreken over dezelfde juridische kwesties, maar gebruiken andere termen voor hetzelfde of dezelfde termen met een andere betekenis, afhankelijk van onze aanvliegroute. Dat leidt soms tot spraakverwarring, maar ook tot wederzijds begrip en (nieuwe) inzichten. Zo ook tijdens dit symposium.

Een veelheid van onderwerpen en implicaties is tijdens het symposium besproken. De verschillende bijdragen in dit themanummer geven hier een goed beeld van. Persoonlijk vind ik het arrest dogmatisch verwarrend, nu het Hof zijn vaste rechtspraak inzake de zwaartepunttheorie eenvoudig terzijde legt. Tegelijkertijd makt het Hof een begrijpelijke praktische keuze door detailhandel in goederen in zijn algemeenheid als dienst in de zin van de richtlijn aan te merken. Dit voorkomt dat per zaak concreet gekeken moet worden naar het zwaartepunt en dat is winst en zorgt voor rechtszekerheid. Wat betreft de interne werking van hoofdstuk III van de richtlijn is de kogel door de kerk, hetgeen alleen maar toe te juichen valt. Het spannendst zijn wat mij betreft de implicaties van het oordeel van het Hof dat voorschriften inzake ruimtelijke ordening niet voorshands zijn uitgesloten van de Dienstenrichtlijn en getoetst moeten worden aan de richtlijn, in het bijzonder aan art. 15 lid 3 van de richtlijn. Dit betekent werk aan de winkel voor bijvoorbeeld gemeenten, denk ik. Zij zullen hun bestemmingsplannen in de komende tijd kritisch moeten gaan bekijken en in sommige gevallen zal een behoorlijke analyse daarvoor nodig zijn. Opvallend vind ik daarbij de geluiden langs de velden en in de pers ${ }^{2}$ dat de implicaties van het arrest voor de dagelijkse bestemmingsplanpraktijk misschien mee zullen vallen. Dit alles - gechargeerd gezegd - onder het motto: 'Als gemeenten hun beslissingen ruimtelijk relevant onderbouwen, dan zal ook voldaan zijn aan de vereisten van artikel 15 lid 3 van de Dienstrichtlijn.' Of die juridische vlieger opgaat, betwij-

1. Vanuit het perspectief van de nationale rechter: C. Wissels, De Afdeling bestuursrechtspraak en de prejudiciële procedure: verantwoordelijkheid en regie, SEW 2015, p. 547-555. Voor een meer algemene uiteenzetting van deze dynamiek: J. Langer, The preliminary ruling procedure: Old problems or new challenges?, 2016, papers.ssrn.com/sol3/papers. cfm?abstract_id=2885256.

2. Zie onder meer B. van Bockel (2017), www.nrc.nl/nieuws/2018/03/09/ gemeente-moet-bestemmingsplan-toetsen-aan-europese-dienstenrichtlijn-a1595074. fel ik. De bewoordingen van art. 15 lid 3 zijn ongelukkig geformuleerd en kunnen tot verwarring leiden. Maar waar het uiteindelijk om gaat, is dat een eis in een bestemmingsplan die de dienstenactiviteit regelt (1) non-discriminatoir is en (2) gerechtvaardigd wordt door een dwingende reden van algemeen belang, en (3a) de gestelde eis geschikt is om die dwingende reden te bereiken, en (3b) de gestelde eis dit op een evenredige wijze doet, dat wil zeggen dat er geen alternatief voorhanden is waarmee het doel ook kan worden bereikt, maar dat minder belemmerend is voor het vrij verkeer van diensten. Vanuit een Europeesrechtelijke blik zijn deze vereisten niet schokkend: dit is vaste rechtspraak van het Hof en gecodificeerd door de Uniewetgever in de Dienstenrichtlijn.

Onder deze vereisten vallen in mijn ogen ook de coherentietoets en proportionaliteit stricto sensu. Uit de rechtspraak van het Hof volgt dat deze coherentietoets valt onder de vraag naar geschiktheid van een maatregel. ${ }^{3}$ De afgelopen jaren duikt steeds vaker in de rechtspraak van het Hof de overweging op dat het doel 'op samenhangende en stelselmatige wijze' moet worden bereikt. $^{4}$ Simpel gezegd is daarmee vereist dat het gevoerde beleid geen tegenstrijdigheden mag bevatten en het doel dus coherent wordt nagestreefd. Gemeenten dienen acht te slaan op deze coherentietoets. Op overeenkomstige wijze dienen gemeenten rekening te houden met proportionaliteit stricto sensu.$^{5}$ Dit aspect van de proportionaliteitstoets kan als volgt worden uitgedrukt: er dient een evenwicht te bestaan tussen het nagestreefde doel en de impact op de vrijverkeersrechten onder het VWEU. De lidstaat dient daarom aan te tonen dat de mate waarin hij zijn legitieme belangen beschermd wenst te zien, in verhouding staat tot de daardoor veroorzaakte belemmeringen van deze vrijheden. Het verschil met de vereisten onder punten $3 \mathrm{a}$ en $3 \mathrm{~b}$ is dat op basis van de uitkomst van de proportionaliteitstoets stricto sensu verlangd kan worden dat een lidstaat een maatregel treft die het vrij verkeer minder belemmert, ook al zou als gevolg daarvan het niveau van bescherming van zijn legitieme belangen lager uitvallen. De proportionaliteitstoets stricto sensu wordt (tot heden in de rechtspraak van het Hof) sporadisch toegepast, maar voorstelbaar is dat dit vereiste onder de Dienstenrichtlijn een belangrijke(re) rol gaat spelen.

De uitdaging voor gemeenten is om voornoemde vereisten van art. 15 lid 3 van de Dienstenrichtlijn te operationaliseren in hun bestemmingsplanpraktijk. Gemeenten zullen met een ruimtelijke onderbouwing een heel eind

3. Ottica New Line di Accardi Vincenzo, zaak C-539/11, ECLI:EU: C:2013:591, punt 47.

4. Scotch Whisky Association and Others/Lord Advocate and Advocate General for Scotland, zaak C-333/14, ECLI:EU:C:2015:845, punt 37 en Gebhart Hiebler/Walter Schlagbauer, zaak C-293/14, ECLI:EU:C: 2015:843, punt 65. Zie ook J. Langer \& W. Sauter, The consistency requirement in EU law, Columbia Journal of European Law 2017, p. 39-73.

5. Zie bijv. A-G Poiares Maduro in Jan-Erik Anders ea/Virallinen syyttäjä, zaak C-434/04, ECLI:EU:C:2006:462, punt 26. 
komen, maar ik ben niet overtuigd dat dit (altijd) voldoende is. Complicerende factor is dat de vereisten van art. 15 lid 3 van de richtlijn zijn opgesteld vanuit het perspectief dat een eis alleen is toegestaan op voorwaarde dat de beperking van het dienstenverkeer gerechtvaardigd is. Dat betekent dat de gemeentelijke eisen vanuit dát perspectief doordacht en gemotiveerd dienen te zijn. De bewijslast in dezen ligt bij de gemeente: zij zal onderbouwd moeten aantonen dat aan voornoemde eisen van de proportionaliteitstoets is voldaan. Het Hof spreekt hierbij over 'deugdelijk bewijs' dat de betrokken autoriteiten moeten aanleveren. ${ }^{6}$ Hoe gedetailleerder de tegenpartij met tegenbewijs komt, hoe zwaarder die bewijslast voor de overheid is, lijkt mij. Met één belangrijke kanttekening: het Hof heeft (ook) duidelijk gemaakt dat deze bewijslast niet betekent dat op de overheid een positieve plicht rust om alle alternatieven te onderzoeken. ${ }^{7}$ De bestuursrechter zal vervolgens na moeten gaan of op grond van de aangedragen motivering en het aangeleverde bewijsmateriaal voldaan is aan de proportionaliteitstoets, mede in het licht van de gevoerde verweren. ${ }^{8}$ Een gezichtspunt daarbij is dat naarmate de aantasting van belangen van betrokkenen groter is, de toetsing intensiever zou moeten zijn. Al met al geen sinecure! Het vereist ook een actieve houding van de bestuursrechter. Een mooi voorbeeld hiervan is de beslissing van de Afdeling betreffende de tijdelijke vergunningen voor rondvaartboten in Amsterdam. ${ }^{9}$ Dogmatisch sluit deze uitspraak goed aan bij de onder de proportionaliteitstoets vereiste stappen. Het vonnis laat ook mooi zien hoe gedetailleerd de Afdeling naar de door de gemeente Amsterdam aangedragen argumenten en bewijsstukken heeft gekeken. Deze actieve toetsingshouding sluit aan bij een reeds zichtbare bredere ontwikkeling in Nederland naar een kritischere beoordeling door de rechter van besluiten van bestuursorganen. ${ }^{10}$ Een dergelijke actieve houding sluit ook goed aan bij de recente conclusie van A-G Widdershoven over de exceptieve toetsing van algemeen verbindende voorschriften. ${ }^{11}$ Hij ziet een prominente rol voor de proportionaliteitstoets en pleit ervoor om de rechterlijke toetsing waar mogelijk te intensiveren en daarbij te toetsen via de drieslag van geschiktheid, noodzakelijkheid en proportionaliteit stricto sensu van een maatregel in relatie tot het nagestreefde doel.

Tot slot: kan de vlag uit in de gemeente Appingedam? Wij zullen het zien. De zaak ligt nu weer op het bord van de Afdeling. De gemeente is aan zet om in het licht

6. Scotch Whisky Association \& Others/Lord Advocate and Advocate General for Scotland, zaak C-333/14, ECLI:EU:C:2015:845, punt 54.

7. Commissie/Italië, zaak C-110/05, ECLI:EU:C:2009:66, punten 66-67.

8. Hartlauer Handelsgesellschaft $\mathrm{mbH} /$ Wiener Landesregierung, zaak C-169/07; Berlington Hungary Tanácsadó és Szolgáltató kft \& Others/ Magyar Állam, zaak C-98/14, ECLI:EU:C:2015:386; Admiral Casinos \& Entertainment AG/Balmatic Handelsgesellschaft $\mathrm{mbH}$ ea, zaak C-464/15, ECLI:EU:C:2016:500

9. ECLI:NL:RVS:2017:1520. Voor een vergelijkbaar voorbeeld in de context van een bestemmingsplan, zie ECLI:NL:RVS:2018:616.

10. Zie T. Barkhuysen (2017), www.njb.nl/blog/de-opmars-van-evenredigheid-in-het-bestuursrecht.28164.lynkx.

11. ECL:NL:RVS:2017:3557 van het arrest van het Hof aan te tonen waarom de gevoerde eis in haar bestemmingsplan de Europeesrechtelijke toets kan doorstaan. Gemotiveerd en op basis van deugdelijk bewijs zal de gemeente moeten aantonen dat voldaan is aan de verschillende elementen van de proportionaliteitstoets. Het is aan de Afdeling om te beoordelen of hieraan op onderbouwde en gemotiveerde wijze is voldaan, mede in het licht van de verweren van belanghebbende. Moge dit themanummer van TO voor die discussie en vergelijkbare discussies in andere zaken nuttig zijn. Veel leesplezier! 